The Highest Good in Kant's Philosophy 



\section{The Highest Good in Kant's Philosophy}

Edited by

Thomas Höwing 
Printed with financial support from the Deutsche Forschungsgemeinschaft (DFG).

ISBN 978-3-11-037428-5

e-ISBN (PDF) 978-3-11-036900-7

e-ISBN (EPUB) 978-3-11-039274-6

\section{Library of Congress Cataloging-in-Publication Data}

A CIP catalog record for this book has been applied for at the Library of Congress.

\section{Bibliographic information published by the Deutsche Nationalbibliothek}

The Deutsche Nationalbibliothek lists this publication in the Deutsche Nationalbibliografie; detailed bibliographic data are available on the Internet at http://dnb.dnb.de.

(C) 2016 Walter de Gruyter GmbH, Berlin/Boston

Cover illustration: Ivary/Thinkstock

Printing and binding: CPI books $\mathrm{GmbH}$, Leck

(2) Printed on acid-free paper

Printed in Germany

www.degruyter.com 